\title{
Frequency of Group A Rotavirus in Piglet Stool Samples from Non-Vaccinated Brazilian Pig Herds
}

\author{
Rita de Cássia Linares ${ }^{1}$, Aline Fernandes Barry ${ }^{1}$, Alice Fernandes Alfieri ${ }^{1}$, Kerlei Cristina \\ Médici $^{1}$, César Feronato ${ }^{2}$, Wladimir Grieder ${ }^{2}$ and Amauri Alcindo Alfieri ${ }^{1 *}$ \\ Laboratório de Virologia Animal; Departamento de Medicina Veterinária Preventiva; Universidade Estadual de \\ Londrina; 86051-990; Londrina - PR - Brasil. ${ }^{2}$ Intervet/Schering-Plough Animal Health; Cotia - SP - Brasil
}

\begin{abstract}
Neonatal diarrhea is one of the main causes of morbidity and mortality in piglets, and it leads to significant economic losses for pig farmers worldwide. The aim of this study was to determine the frequency of diagnosis, age group, and association of group A rotavirus (GARV) infection with diarrhea in piglets from pig herds in two (south and center-west)Brazilian geographical regions. The frequency of GARV diagnosis was evaluated between 2004 and 2007, using SS-PAGE on 681 fecal samples (428 diarrheic and 253 with normal consistency) from 1-4 week-old piglets. The animals were selected from 130 pig herds and 80 counties in the states of Rio Grande do Sul, Santa Catarina, Paraná, Mato Grosso do Sul, and Mato Grosso, Brazil. None of the herds were vaccinated against porcine GARV. Rotaviruses with the typical GARV electrophoretic pattern was identified in 193 (28.3\%) fecal samples, and of these, $157(81.3 \%)$ were diarrheic $(p=0.001)$.Porcine GARV infection was identified in animals from all age groups evaluated, and the highest infection rate (54.7\%; $p=0.001)$ occurred in diarrheic piglets between 21 and 28 days of age. Diarrheic feces from 1-7 day-old piglets also had a high rate of rotavirus presence $(32.3 \%)$, suggesting a failure in passive immunity. The high rate of porcine GARV infection in all geographical regions studied demonstrates the involvement of rotavirus in the etiology of neonatal diarrhea in Brazilian pig herds. This study highlights the importance of GARV infection for pig raising and the need of control and prophylactic measures for porcine rotavirus infection, including vaccination in the main areas of pork production in Brazil.
\end{abstract}

Key words: piglet, neonatal diarrhea, group A rotavirus, SS-PAGE

\section{INTRODUCTION}

Diarrhea in piglets is a major endemic health problem for pig herds worldwide. In intensive pig farms, neonatal diarrhea results in direct and indirect economic losses that are mainly due to the high cost of treatment, higher susceptibility to other infections (e.g., respiratory diseases), nonuniformity of litters to weaning, and death of animals (Svensmark et al., 1989; Alfieri et al., 1991).

The causes of diarrhea in piglets are multi-factorial and multi-etiological. Factors related to animal production, health management, and the presence of enteropathogenic microorganisms predisposes young animals to infection. Several classes of microorganisms, such as bacteria (E. coli, Clostridium perfringens type $\mathrm{C}$ ), protozoa

\footnotetext{
*Author for correspondence: alfieri@uel.br
} 
(Cryptosporidium spp, Isospora suis), and viruses (rotavirus, coronavirus, calicivirus), can cause enteritis in piglets in both single and mixed infections (Driesen et al., 1993; Alfieri et al., 1994; Calderaro et al., 2001; Wieler et al., 2001; Barry et al., 2008a; 2008b; Zlotowski et al., 2008).

Worldwide, rotavirus is the main viral etiological agent of diarrhea in young mammals and some avian species (Parashar et al., 2003; Tamehiro et al., 2003). Rotaviruses belong to the Reoviridae family. They have icosahedral symmetry and a non-enveloped capsid formed by three concentric layers of protein that is $70-90 \mathrm{~nm}$ in diameter. Their genome is composed of 11 double-stranded RNA segments (dsRNA). Based on the common group antigen (VP6 protein), rotaviruses are classified antigenically into seven serogroups (A$\mathrm{G})$. The co-migration of genomic segments 7,8 , and 9 in polyacrylamide gel electrophoresis (PAGE) is an important characteristic of group A rotaviruses (Estes, 1996).

Around the world, including in Brazil, group A rotaviruses (GARV) are directly involved in diarrhea episodes in suckling and weaned piglets (Gatti et al., 1989; Alfieri et al., 1991; Alfieri et al., 1999; Dewey et al., 2003; Katsuda et al., 2006).

To diagnose rotavirus, several techniques have been developed to detect the viral particle (cell culture, electron microscopy, immune electron microscopy), antigens, (ELISA, latex agglutination, direct immunofluorescence) and the viral genome (PAGE, RT-PCR). All of these methods vary in specificity and sensitivity and carry both advantages and disadvantages (Alfieri et al., 1996; Markowska-Daniel et al., 1996).

Epidemiological studies with high numbers of analyzed samples must carefully select diagnostic assays by evaluating the sensitivity and specificity of the technique, the cost, and the ease of execution. PAGE followed by silver staining (SSPAGE) has all of the necessary characteristics for large-scale use. Additionally, SS-PAGE enables the identification of rotavirus groups $\mathrm{A}, \mathrm{B}$, and $\mathrm{C}$ through the analysis of the migration pattern of the 11 dsRNA segments, as well as rotavirus strain electropherotype analysis (Markowska-Daniel et al., 1996).
In Brazil, pork production is an important segment of agribusiness. It holds a significant position in meat production for both in-country consumption and exportation. The identification and control of endemic infections affecting productivity (e.g., diarrhea in suckling and weaned piglets) can contribute to reductions in pork production costs. Despite the importance of rotaviruses in neonatal enteric infections worldwide, the majority of epidemiological studies in Brazil have been restricted to small sampling or very limited geographical areas. The present study aims to determine the prevalence of porcine GARV and to collect epidemiological data regarding GARV infection of Brazilian pig herds.

\section{MATERIALS AND METHODS}

\section{Stool samples}

In the period between June 2004 and April 2007, 681 stool samples were collected from 1-4 weekold piglets. From that total, 428 and 253 were from diarrheic and asymptomatic piglets (control group), respectively. The samples originated from 130 pig herds from 80 counties in 5 different states (Rio Grande do Sul, Santa Catarina, Paraná, Mato Grosso do Sul, and Mato Grosso) and two geographical regions (South and Center-West) of Brazil. At the time of collection, none of the farms used a GARV vaccination program as a prophylactic measure against neonatal diarrhea. The distribution of samples according to their origin is presented in Table 1.

\section{Virus and cells}

The positive control porcine group A rotavirus (OSU) strain was propagated in MA-104 cells and maintained in Dulbecco's Eagle Media (Gibco BRL, USA), supplemented with $10 \%$ fetal bovine serum (Gibco BRL, USA), gentamicin $(55 \mu \mathrm{g} / \mathrm{mL})$ (Sigma Co., USA), and amphotericin B (2.5 $\mu \mathrm{g} / \mathrm{mL}$ ) (Bristol-Meyers Squibb, Brazil) (Sato et al., 1981). This GARV strain was used as positive control in SS-PAGE. 
Table 1 - Origin and characteristics of stool samples from piglets used for porcine group A rotaviruses detection in Brazilian pig herds.

\begin{tabular}{lccccc}
\hline \multirow{2}{*}{ State } & \multirow{2}{*}{ County } & \multirow{2}{*}{ Herd } & \multicolumn{2}{c}{ Fecal Samples } & \multirow{2}{*}{ Total } \\
\cline { 4 - 5 } & & & Diarrheic & Non-diarrheic & \\
\hline Paraná & 23 & 51 & 126 & 108 & 234 \\
Santa Catarina & 15 & 22 & 99 & 57 & 156 \\
Rio Grande do Sul & 38 & 49 & 151 & 73 & 224 \\
Mato Grosso do Sul & 1 & 3 & 15 & 9 & 24 \\
Mato Grosso & 3 & 5 & 37 & $\mathbf{2 5 3}$ & $\mathbf{6 8 1}$ \\
\hline \multicolumn{1}{c}{ Total } & $\mathbf{8 0}$ & $\mathbf{1 3 0}$ & $\mathbf{4 2 8}$ & &
\end{tabular}

\section{RNA extraction}

Fecal suspensions $(20 \% \mathrm{w} / \mathrm{v})$ in $\mathrm{Tris} / \mathrm{Ca}^{++}$buffer (50 mM Tris- $\mathrm{HCl} ; 10 \mathrm{mM} \mathrm{NaCl} ; 1.5 \mathrm{mM} \mathrm{2-}$ mercaptoetanol; $3 \mathrm{mM} \mathrm{CaCl} 2$ ) were centrifuged at $3,000 \mathrm{x} \mathrm{g}$ for $15 \mathrm{~min}$ at $4{ }^{\circ} \mathrm{C}$. Aliquots of $400 \mu \mathrm{L}$ of supernatant were treated with SDS (1\% final concentration) and incubated for $30 \mathrm{~min}$ at $56{ }^{\circ} \mathrm{C}$. A combination of the phenol/chloroform/isoamyl alcohol and silica/guanidine isothiocyanate techniques (Alfieri et al., 2006) was used for nucleic acid extraction. The RNA was eluted in 30 $\mu \mathrm{L}$ of ultra-pure RNase-free, DEPC-treated, sterile water and used for the SS-PAGE technique.

\section{SS-PAGE}

Polyacrylamide gel electrophoresis (7.5\%) followed by silver staining (SS-PAGE) was performed according to Herring et al. (1982) and Pereira et al. (1983), respectively.

\section{Statistical analysis}

The chi-square test $\left(\chi^{2}\right)(\mathrm{p}<0.05)$ was used to evaluate the differences between porcine GARVpositive and -negative stool samples, including fecal characteristics (diarrheic/non-diarrheic) and piglet age. Statistical analysis was performed using Epi Info $^{\mathrm{TM}}$ software, version $6.04 \mathrm{~d}$ (Dean et al., 1998).

\section{RESULTS AND DISCUSSION}

Of the 681 stool samples analyzed, 193 (28.3\%) tested positive for rotaviruses with the electrophoretic profile of group A. The $36.7 \%$ frequency (157/428) of rotavirus diagnosis in fecal samples from piglets with diarrhea was significant $(p=0.0001)$ when compared to the frequency $(36 / 253 ; 14.2 \%)$ in asymptomatic piglets (control group). The chance of diarrheic feces testing positive for rotavirus was increased 3.49-fold over that of normal feces (Table 2).

Table 2 - Porcine group A rotaviruses detected by silver stained polyacrylamide gel electrophoresis (SS-PAGE) in stool samples from diarrheic and asymptomatic (control) piglets.

\begin{tabular}{cccc}
\hline \multirow{2}{*}{ Stool samples } & \multicolumn{2}{c}{ SS-PAGE } & \multirow{2}{*}{ Total } \\
\cline { 2 - 4 } & Positive (\%) & Negative (\%) & 428 \\
Diarrheic & $157(36.7)^{\mathrm{a}}$ & $271(63.3)$ & 253 \\
Non-diarrheic & $36(14.2)$ & $217(85.8)$ & $\mathbf{6 8 1}$ \\
\hline Total & $\mathbf{1 9 3}(\mathbf{2 8 . 3})$ & $\mathbf{4 8 8}(\mathbf{7 1 . 7})$ &
\end{tabular}

Rotavirus was identified in the feces of one-to-four week-old piglets. Age did not play a role in the frequency of infection. However, in diarrheic samples, there was a significant difference $(p=0.0018)$ between GARV frequency in the age groups (Table 3 ); $54.7 \%$ of the 4 week-old piglets tested positive for rotavirus infection. There were no significant differences $(p=0.054)$ between groups when the same variables were analyzed in normal feces (Tables 4).

Worldwide, rotavirus is considered one of the main enteric infections in suckling and weaned piglets (Wieler et al., 2001; Dewey et al., 2003; Katsuda et al., 2006). There have been a few studies in Brazil that examined the frequency of GARV diagnosis in piglet diarrhea episodes, and those had very delimitated geographical regions or 
relatively small sampling (Gatti et al., 1989; Alfieri et al., 1999; Barreiros et al., 2003). The present study evaluated a large number of diarrheic and non-diarrheic piglet stool samples from pig farms in very distinct geographical regions. The results demonstrate that porcine GARV causes neonatal diarrhea episodes in all of the regions studied, showing its wide distribution in Brazilian pig herds. In addition, these areas are regarded as the main pork production regions in the country, which also increases the importance of these results in the economic aspect.

In previous studies conducted in Brazil, the frequency of porcine GARV-positive stool samples varied between $10.9 \%$ and $34.2 \%$, depending on the sampling and diagnostic techniques used (Kroeff et al., 1999; Rácz et al., 2000; Calderaro et al., 2001). The present study identified a frequency (28.3\%) of positive samples that is very similar to those found in previous studies, but did so with a very large number of samples from controls and pre- and post-weaned piglets.

Rotavirus was identified in $36.7 \%$ of diarrheic samples. This rate was greater than that reported in some previous studies conducted in Brazil, including those that used direct ELISA as the diagnostic method. Compared to SS-PAGE, ELISA has a much higher sensitivity (MarkowskaDaniel et al., 1996).

Table 3 - Porcine group A rotavirus detected by silver stained polyacrylamide gel electrophoresis (SS-PAGE) in diarrheic stool samples of piglets with one to four-weeks old.

\begin{tabular}{cccc}
\hline \multirow{2}{*}{ Age (week) } & \multicolumn{2}{c}{ Stool Samples } & \multirow{2}{*}{ Total } \\
\cline { 2 - 3 } & Positive (\%) & Negative (\%) & 127 \\
First & $41(32.3)$ & $86(67.7)$ & 110 \\
Second & $31(28.2)$ & $79(71.8)$ & 116 \\
Third & $44(37.9)$ & $72(62.1)$ & 75 \\
Fourth & $41(54.7)$ & $34(45.3)$ & $\mathbf{4 2 8}$ \\
\hline Total & $\mathbf{1 5 7 ( 3 6 . 7 )}$ & $\mathbf{2 7 1 ( 6 3 . 3 )}$ &
\end{tabular}

$\left(\chi^{2}=15 ; p=0.0018\right)$

Table 4 - Porcine group A rotavirus detected by silver stained polyacrylamide gel electrophoresis (SSPAGE) in stool samples from asymptomatic (control group) piglets with one to four-weeks old.

\begin{tabular}{cccc}
\hline \multirow{2}{*}{ Age (week) } & \multicolumn{2}{c}{ Stool Samples } & \multirow{2}{*}{ Total } \\
\cline { 2 - 3 } & Positive (\%) & Negative (\%) & 96 \\
First & $8(8.3)$ & $88(91.7)$ & 58 \\
Second & $9(15.5)$ & $49(84.5)$ & 58 \\
Third & $14(24.1)$ & $44(75.9)$ & 41 \\
Fourth & $5(12.2)$ & $36(87.8)$ & $\mathbf{2 5 3}$ \\
\hline Total & $\mathbf{3 6}(\mathbf{1 4 . 2})$ & $\mathbf{2 1 7}(\mathbf{8 5 . 8})$ &
\end{tabular}

$\left(\chi^{2}=7.62 ; p=0.054\right)$

It is evident that rotavirus is directly linked to diarrhea as 157 of the 193 positive samples $(81.3 \%)$ were from diarrheic piglets, while only 36 $(18.6 \%)$ were from asymptomatic animals. However, the $14.2 \%$ ( $n=36$ ) of control group fecal samples that tested positive may have simply been taken from piglets prior to the development of clinical signs of diarrhea (Svensmark et al., 1989). It was not possible to evaluate the period of onset or the end of the diarrhea episode, as each farm was sampled only once. The presence of rotavirus in normal feces can only be established through a longitudinal study to follow the litter for the entire suckling and post-weaned period.

The animals were distributed in groups by age (in weeks) to determine if piglets were more susceptible to rotavirus infection at a certain age. Piglets were weaned at 21 days. GARV was identified in the feces of asymptomatic animals in all age groups, but it was mainly present in animals with diarrhea, which demonstrates that rotaviruses are widely disseminated in the pig herds evaluated. There was a higher (54.7\%) frequency of positive diagnosis in 21-28 day-old 
piglets with diarrhea. During this period, the passive antibody titer is the lowest since birth, and the active immune system has not fully matured (Askaa et al., 1983; Dewey et al., 2003). Additionally, all piglets were in the same place and under the same environmental, social, nutritional, and management stresses, as they were recently weaned. Therefore, animals in this age group are very susceptible to enteric infections, which may account for the high frequency of stool samples positive for rotavirus.

This investigation has demonstrated that porcine rotavirus is widely spread in pig herds throughout the main pork producing regions of Brazil, and it is directly associated with diarrheal episodes occurring in post-weaned piglets. A higher frequency of positive diagnosis for GARV in diarrheic stool samples was observed in three-tofour week-old piglets. Considering that neonatal diarrhea is the major endemic health problem in pig herds worldwide and the high prevalence of porcine GARV infection found in Brazilian pig herds, programs for control and prophylaxis should be implemented and monitored.

\section{ACKNOWLEDGEMENTS}

The financial resources for the conduction of this study were supported by the project BioAgroPar financed by FINEP, SETI/PR, and Fundação Araucária/PR; and by CNPq/Brazil.

Part of the research activities of this study was carried out in the Agricultural Research Support Laboratory (Laboratório de Apoio à Pesquisa Agropecuária - LAPA) / PROPPG / UEL.

Alfieri, A.A. and Alfieri, A.F. are recipients of CNPq fellowships.

\section{RESUMO}

A diarréia neonatal é uma das principais causas de morbidade e mortalidade em leitões, ocasionando consideráveis prejuízos econômicos à suinocultura em todo o mundo. O objetivo desse estudo foi determinar a frequência de diagnóstico, distribuição etária e a associação com diarreia da infecção por rotavírus grupo A (GARV) em leitões de granjas situadas em duas (sul e centro-oeste) regiões geográficas brasileiras. A frequência de diagnóstico do GARV foi avaliada no período de 2004 a 2007, pela técnica de SS-PAGE, em 681 amostras fecais (428 diarréicas e 253 com consistência normal) de leitões de 1 a 4 semanas de idade. Os animais eram provenientes de 130 granjas, localizadas em 80 municípios dos estados do Rio Grande do Sul, Santa Catarina, Paraná, Mato Grosso do Sul e Mato Grosso. Nenhum dos rebanhos realizava vacinação contra o GARV suíno. Rotavírus suíno com perfil eletroforético característico do grupo A foi detectado em 193 $(28,3 \%)$ amostras, das quais $157 \quad(81,3 \%)$ diarreicas $(p=0,001)$. A infecção foi identificada em animais de todas as faixas etárias avaliadas e a maior frequência $(54,7 \% ; p=0,001)$ de diagnóstico ocorreu em leitões diarréicos com 21 a 28 dias de idade. A alta taxa $(32,3 \%)$ de diagnóstico do rotavírus em fezes diarreicas de leitões com 1 a 7 dias de vida sugere a necessidade da adoção de condutas que objetivem o incremento da imunidade passiva. A frequência de diagnóstico e a ampla distribuição das infecções pelo GARV, nos rebanhos das regiões geográficas avaliadas nesse estudo, ratificam a importância da rotavirose na etiologia dos episódios de diarreia de leitões no Brasil. Este resultado destaca também a importância do controle e medidas profiláticas na infecção por rotavírus suíno, incluindo a vacinação nas principais áreas de produção suína no Brasil.

\section{REFERENCES}

Alfieri, A. A., Alfieri, A. F., Conte, L. E., Resende, M. (1991), Evidências do envolvimento de rotavírus nas diarréias do pré e pós-desmame dos suínos. Arq Bras Med Vet Zootec, 43, 291-300

Alfieri, A. A., Alfieri, A. F., Freitas, J. C., Silva, C. A., Freire, R. L., Barros, A. R., Barreiros, M. A. B., Muller, E. E. (1994), Ocorrência de Escherichia coli, Rotavírus, Picobirnavírus e Cryptosporidium parvum em um foco de diarréia do pós-desmame em suínos. Semina Ci Agr, 15, 5-7

Alfieri, A. A., Leite, J. P. G., Nakagomi, O., Kaga, E., Woods, P. A., Glass, R. I., Gentsch, J. R. (1996), Characterization of human rotavirus genotype $\mathrm{P}$ [8],G5 from Brazil by probe-hybridization and sequence. Arch Virol, 141, 2353-2364

Alfieri, A. A., Alfieri, A. F., Beuttemmüller, E. A., Brito, B. G., Médici, K. C. (1999), Aspectos epidemiológicos da rotavirose suína na região Sudoeste do Estado do Paraná, Brasil. Semina Ci Agr, 20, 5-11 
Alfieri, A. A., Parazzi, M. E., Takiuchi, E., Médici, K. C., Alfieri, A. F. (2006), Frequency of group A rotavirus in diarrhoeic calves in Brazilian cattle herds, 1998-2002. Trop Anim Health Prod, 38, 521-526

Askaa, J., Bloch, B., Bertelsen, G., Rasmussem, K. O. (1983), Rotavirus associated diarrhoea in nursing piglets and detection of antibody against rotavirus in colostrum, milk and serum. Nord Vet Med, 35, 441447

Barreiros, M. A., Alfieri, A. A., Alfieri, A. F., Medici, K. C., Leite, J. P. G. (2003), An outbreak of diarrhoea in one-week-old piglets caused by group A rotavirus genotypes P[7],G3 and P[7],G5. Vet Res Commun, 27, 505-512

Barry, A. F., Alfieri, A. F, Alfieri, A. A. (2008a), Detection and phylogenetic analysis of porcine enteric calicivirus, genetically related to the Cowden strain of sapovirus genogroup III, in Brazilian swine herds. Braz J Vet Res, 28, 82-86

Barry, A. F., Alfieri, A. F., Alfieri, A. A. (2008b), High genetic diversity in RdRp gene of Brazilian porcine sapovirus strains. Vet Microbiol, 131, 185-191.

Calderaro, F. F., Baccaro, M. R., Moreno, A. M., Ferreira, A. J. P., Jerez, A. J., Pena, H. J. F. (2001), Frequência de agentes causadores de enterites em leitões lactantes provenientes de sistemas de produção de suínos do Estado de São Paulo. Arq Inst Biol, 68, 29-34

Dean, A. G., Dean, J. A., Coulombier, D., Burton, A. H., Brendel, K. A., Smith, D. C., Dicker, R. C., Sullivan, K. M., Fagan, R. F., Arne, T. G. (1998), Epi Info versão 6.04.d. Disponível em <www.cdc.gov/epiinfo/Epi6/EI6dnj.htm>.

Dewey, C., Carman, S., Pasma, T., Josephson, C., Mcewen, B. (2003), Relationship between group A porcine rotavirus and management practices in swine herds in Ontario. Can Vet J, 44, 649-653

Driesen, S. J., Carland, P. G., Fahy, V. A. (1993), Studies on preweaning piglet diarrhoea. Aust Vet J, 70, 259-262

Estes, M. (1996), Rotaviruses and their replication. InFields Virology, 3ed. Raven Press, New York, pp.1625-1655

Gatti, M. S. V., Hara, N. H., Ferraz, M. M. G., Pestana De Castro, A. F. (1989), Presence of group A and non-A rotaviruses in neonatal piglets in Campinas, SP, Brazil. Med Microbiol Immunol, 178, 347-349

Herring, A. J., Inglis, N. F., Ojeh, C. K., Snodgrass, D. R., Menzies, J. D. (1982), Rapid diagnosis of rotavirus infection by direct detection of viral nucleic acid in silver-stained polyacrylamide gels. J Clin Microbiol, 16, 473-477
Katsuda, K., Kohmoto, M., Kawashima, K., Tsunemitsu, H. (2006), Frequency of enteropathogen detection in suckling and weaned pigs with diarrhea in Japan. J Vet Diagn Invest, 18, 350-354

Kroeff, S. S., Munford, V., Rácz, M. L., Hayashi, Y. (1999), Caracterização sorológica e molecular de rotavírus suíno no Paraná - Brasil. Arch Vet Sci, 4, 123-127

Markowska-Daniel, I., Winiarczyk, S., Gradzki, Z., Pejsak, Z. (1996), Evaluation of different methods (ELISA, IF, EM, PAGE) for the diagnosis of rotavirus infection in piglets. Comp Immun Microbiol Infect Dis, 19, 219-232

Parashar, U. D., Hummelman, E. G., Bresee, J. S., Miller, M. A., Glass, R. I. (2003), Global Illness and Deaths Caused by Rotavirus Disease in Children. Emerg Infect Dis, 9, 565-572

Pereira, H. G., Azeredo, R. S., Leite, J. P. G, Candeias, J. A. N., Racz, M. L., Linhares, A. C., Gabbay, Y. B., Trabulsi, J. R. (1983), Electrophoretic study of the genome of human rotaviruses from Rio de Janeiro, São Paulo and Belem, Brazil. J Hyg, 90, 117-125

Rácz, M. L., Kroeff, S. S., Munford, V., Caruzo, T. A. R., Durigon, E., Hayashi, Y., Gouvea, V., Palombo, E. A. (2000), Molecular characterization of porcine rotavirus from the Southern region of Brazil: characterization of atypical genotype G9 strain. J Clin Microbiol, 38, 2443-2446

Sato, K., Inaba, Y., Shinozaki, T., Fujii, R., Matumoto, M. (1981), Isolation of human rotavirus in cell cultures. Arch Virol, 69, 155-160

Svensmark, B., Nielsen, K., Dalsgaard, K., Willeberg, P. (1989), Epidemiological studies of piglet diarrhea in intensively managed Danish sow herds. Acta Vet Scand, 30, 63-70

Tamehiro, C. Y., Alfieri, A. F., Medici, K. C., Alfieri, A. A. (2003), Segmented double-stranded genomic RNA viruses in faecal samples from broiler chicken. Braz J Microbiol, 34, 349-35

Wieler, L. H., Llieff, A., Herbest, W., Bauer, C., Vieler, E., Bauerfeind, R., Failing, K., Klos, H., Wengert, D., Baljer, G., Zahner, H. (2001), Prevalence of enteropathogens in suckling and weaned piglets with diarrhoea in Southern Germany. J Vet Med B Infect Dis Vet Public Health, 48, 151-159

Zlotowski, P., Corrêa, A. M. R., Barcellos, D. E. S. N., Cruz, C. E. F., Asanome, W., Barry, A. F., Alfieri, A. A., Driemeier, D. (2008), Intestinal lesions in pigs affected with postweaning multisystemic wasting syndrome. Braz J Vet Res, 28, 313-318 